\title{
PENGARUH MODEL PEMBELAJARAN KOOPERATIF GROUP INVESTIGATION TERHADAP KEMAMPUAN BERPIKIR KRITIS DITINJAU DARI BAKAT NUMERIK BAGI SISWA KELAS XI SMA
}

\author{
Sri Artini, Ni Nyoman \\ Jurusan Teknologi Pembelajaran \\ Email:rhomin_aswin@yahoo.com
}

\begin{abstract}
ABSTRAK
Penelitian ini bertujuan untuk menganalisis (1) perbedaan kemampuan berpikir kritis antara siswa yang mengikuti model pembelajaran kooperatif Group Investigation dengan siswa yang mengikuti model pembelajaran langsung, (2) pengaruh interaksi antara model pembelajaran dengan bakat numerik siswa terhadap kemampuan berpikir kritis siswa, (3) perbedaan kemampuan berpikir kritis antara siswa yang mengikuti model pembelajaran kooperatif Group Investigation dengan siswa yang mengikuti model pembelajaran langsung, pada siswa yang memiliki bakat numerik tinggi, (4) perbedaan kemampuan berpikir kritis antara siswa yang mengikuti model pembelajaran kooperatif Group Investigation dengan siswa yang mengikuti model pembelajaran langsung, pada siswa yang memiliki bakat numerik rendah. Jenis penelitian ini adalah penelitian eksperimen semu dengan rancangan yang digunakan adalah two way pretest-posttest non-equivalent control group design. Populasi penelitian adalah siswa kelas XI IA SMAN 2 Semarapura tahun pelajaran 2013/2014 sebanyak 171 orang. Sampel 76 orang siswa yang dipilih dengan teknik simple random sampling dengan uji kesetaraan kelas. Data dalam penelitian ini berupa kemampuan berpikir kritis dan bakat numerik siswa yang dikumpulkan dengan tes kemampuan berpikir kritis dan bakat numerik. Pengujian hipotesis menggunakan uji ANAVA dua jalur dan dilanjutkan dengan uji Scheffe untuk menguji komparasi pasangan nilai rata-rata tiap kelompok perlakuan.

Hasil penelitian menunjukkan (1) terdapat perbedaan yang signifikan antara kemampuan berpikir kritis kelompok siswa yang belajar dengan model pembelajaran kooperatif Group Investigation dan model pembelajaran langsung $(\mathrm{Fh}=14,153 ; \mathrm{p}<0,05)$. Siswa yang belajar dengan model pembelajaran kooperatif Group Investigation menunjukkan kemampuan berpikir kritis dan bakat numerik yang lebih baik. (2) Terdapat pengaruh interaksi antara model pembelajaran dan bakat numerik terhadap kemampuan berpikir kritis $(\mathrm{Fh}=4,502 ; \mathrm{p}<0,05)$. (3) Terdapat perbedaan yang signifikan antara tingkat kemampuan berpikir kritis siswa yang belajar dengan model pembelajaran kooperatif Group Investigation dan siswa yang belajar dengan model pembelajaran langsung untuk kelompok siswa yang memiliki bakat numerik tinggi $\left(F h=16,68>F^{\prime}(0,05)=4,41\right)$. (4) Terdapat perbedaan yang signifikan antara tingkat kemampuan berpikir kritis siswa yang belajar dengan model pembelajaran kooperatif Group Investigation dan siswa yang belajar dengan model pembelajaran langsung untuk kelompok siswa yang memiliki bakat numerik rendah $\left(\mathrm{Fh}=1,29>\mathrm{F}^{\prime}(0,05)=4,41\right)$.
\end{abstract}

Kata Kunci: Model Pembelajaran Kooperatif Group Investigation, Kemampuan Berpikir Kritis, Bakat Numerik.

\begin{abstract}
Sri Artini, Ni Nyoman. 2016. The Influence of Group Investigation Cooperative Learning Model towards Critical Thinking Ability in terms of Numerical Talent for Senior High School Student grade XI. Thesis. Singaraja: The Postgraduate Program of Undiksha University. This thesis has been approved and corrected by the first supervisor: Prof. Dr. I Made Candiasa, MIKomp, and the second supervisor: Dr. I Made Kirna, M.Si. This research aimed to analyze (1) the difference of critical thinking ability among the students who joined Group Investigation cooperative learning model with the students who take the direct learning model, (2) interaction effect between learning model and students' numerical talent towards students' critical thinking ability, (3) the difference of critical thinking ability among the students who joined Group Investigation cooperative learning model with the students who take the
\end{abstract}


direct learning model, on high numerical talent students, (4) the difference of critical thinking ability among the students who joined Group Investigation cooperative learning model with the students who take the direct learning model, on low numerical talent students. The research type was a quasi experimental research with two ways pretest-posttest non-equivalent control group design. The research population was grade XI A1 students of SMAN 2 Semarapura Academic Year 2013/2014, with the amount 171 students. The sample was 76 students chosen by simple random sampling technique and class equality test. The data research was critical thinking ability and students' numerical talent collected by critical thinking ability test and numerical talent. The hypothesis testing used ANOVA two paths followed by Scheffe test to test the comparative value pairs on average each treatment group.

The research result showed (1) there was a significant difference between critical thinking ability of the students using Group Investigation cooperative learning model and direct learning model $(F h=14,153 ; p<0,05)$. The students learnt using Group Investigation cooperative learning model showed better critical thinking ability and numerical talent. (2) There was an interaction effect between learning model and numerical talent towards critical thinking ability $(\mathrm{Fh}=4,502 ; \mathrm{p}<0,05)$. (3) There was a significant difference between critical thinking ability students' levels that using Group Investigation cooperative learning model and direct learning model on high numerical talent students $\left(F h=16,68>F^{\prime}(0,05)=4,41\right)$. (4) There was a significant difference between critical thinking ability of the students using Group Investigation cooperative learning model and direct learning model for low numerical talent students $\left(\mathrm{Fh}=1,29>\mathrm{F}_{(0,05)}^{\prime}=4,41\right)$.

Key Words: Group Investigation Cooperative Learning Model, Critical Thinking Ability, Numerical Talent.

\section{PENDAHULUAN}

Pembelajaran matematika saat ini adalah mengembangkan HighOrder Thinking Skills (HOTS) dan menjadikannya sebagai tujuan utama dalam pembelajaran matematika. Pernyataan ini antara lain dinyatakan oleh The National Education Association Research Division yang menyatakan "Student Acquisition of high-order thinking skills is now a nation goal' (Ghokhale, 1997:1). Sejalan dengan hal tersebut, salah satu harapan yang ingin dicapai dalam pembelajaran matematika di sekolah adalah dimilikinya kemampuan berpikir matematis, khusunya berpikir matematis tingkat tinggi.

Tujuan pembelajaran matematika khusunya pada jenjang pendidikan menengah adalah agar siswa memiliki kemampuan: (1) memahami konsep matematika, menjelaskan keterkaitan antar konsep dan mengaplikasikan konsep atau algoritma secara luwes, akurat, efisien, dan tepat dalam pemecahan masalah; menggunakan penalaran pada pola dan sifat, melakukan manipulasi matematika dalam membuat generalisasi, menyusun bukti, atau menjelaskan gagasan dan pernyataan matematika; (3) memecahkan masalah yang meliputi kemampuan memahami masalah, merancang model matematika, menyelesaikan model dan menafsirkan solusi yang diperoleh; (4) mengkomunikasikan gagasan dengan simbol, tabel, diagram, atau media lain untuk memperjelas keadaan atau masalah; (5) memiliki sikap menghargai kegunaan matematika dalam kehidupan, yaitu memiliki rasa ingin tahu, perhatian, dan minat dalam mempelajari matematika, serta sikap ulet dan percaya diri dalam pemecahan masalah (BSNP, 2006).

Selama ini pembelajaran matematika yang dilakukan di sekolahsekolah cenderung masih bersifat konvensional dan kurang mengembangkan High-Order Thinking Skills (HOTS). Pembelajaran lebih mengutamakan hasil atau produk, dan 
hanya sedikit yang mengarah pada proses. Ini menyebabkan ilmu yang didapat oleh siswa hanya berupa konsep, teori atau hukum yang dihapalkan, terasa kering dan tak bermakna. Dalam pembelajaran matematika yang paling penting adalah proses karena melalui proses anak akan memiliki keterampilan matematis dan akan terbentuk sikap (attitude) ilmiah pada siswa. Untuk membuat pembelajaran matematika menjadi bermakna dan berorientasi pada proses, guru harus mampu menerapkan dan melatihkan keterampilan matematis, memilih model pembelajaran yang sesuai, dan mengkombinasikan model dan strategi pembelajaran dengan karakteristik materi, sehingga diperoleh pembelajaran yang inovatif.

Salah satu tujuan dari

penggunaan model pembelajaran adalah untuk meningkatkan kemampuan siswa selama belajar. Dengan pemilihan metode, strategi, pendekatan serta teknik pembelajaran, diharapkan adanya perubahan dari mengingat (memorizing) atau menghapal (rote learning) ke arah berpikir (thinking) dan pemahaman (understanding), dari belajar individual ke kooperatif, serta terkonstruksinya pengetahuan siswa (Setiawan, 2005). Model pembelajaran kooperatif bukanlah hal yang sama sekali baru bagi guru. Model pembelajaran kooperatif merupakan suatu model pembelajaran yang mengutamakan adanya kelompok-kelompok. Setiap siswa yang ada dalam kelompok mempunyai tingkat kemampuan yang berbeda-beda (tinggi, sedang dan rendah) dan jika memungkinkan anggota kelompok berasal dari ras, budaya, suku yang berbeda serta memperhatikan kesetaraan gender. Model pembelajaran kooperatif mengutamakan kerja sama dalam menyelesaikan permasalahan untuk menerapkan pengetahuan dan keterampilan dalam rangka mencapai tujuan pembelajaran.

Untuk menghadapi tantangan perubahan paradigma pendidikan diperlukan sumber daya yang memiliki kemampuan tinggi yang melibatkan pemikiran kritis, sistematis, logis, kreatif dan kemampuan bekerja sama yang efektif. Cara berpikir tersebut dapat dikembangkan melalui pendidikan matematika. Selain itu, dalam aspek pemecahan masalah matematika diperlukan pemikiranpemikiran kritis dalam membuat (merumuskan), menafsirkan dan menyelesaikan model atau perencanaan pemecahan masalah. Dengan demikian, diperlukan suatu cara atau metode yang mendorong kemampuan berpikir kritis siswa dalam belajar matematika.

Kemampuan berpikir kritis yang dimiliki siswa sangat membantu dalam menentukan informasi yang penting didapatkan, diubah, ditransformasi dan dipertahankan. Ada beberapa keuntungan yang diperoleh dari proses belajar mengajar yang memberi penekanan pada kemampuan berpikir yaitu: (1) belajar lebih ekonomis, artinya bahwa apa yang diperoleh dari proses pembelajaran akan bertahan lama dalam benak siswa, (2) cenderung menambah semangat belajar, gairah belajar (antusias) baik pada guru maupun siswa, (3) siswa diharapkan mempunyai sikap ilmiah, dan (4) siswa mempunyai keterampilan memecahkan masalah, baik pada saat pembelajaran di kelas maupun dalam menghadapi permasalahan nyata dalam kehidupan sehari-hari (Redhana, 2003).

Berkaitan dengan uraian yang telah dikemukakan di atas, maka peneliti mencoba menerapkan model pembelajaran kooperatif Group 
Investigation dalam pembelajaran matematika untuk melihat apakah terdapat pengaruh positif antara model pembelajaran yang dilaksanakan terhadap kemampuan berpikir kritis siswa. Di samping itu dalam penelitian ini juga melibatkan aspek psikologis siswa yaitu bakat numerik. Bakat numerik digunakan untuk memprediksi kemampuan berpikir kritis siswa yang dikaitkan dengan model pembelajaran yang digunakan.

Pembelajaran

kooperatif

merupakan model pembelajaran yang menuntut kerja sama antar siswa sehingga dapat memaksimalkan penguasaan materi. Dalam pembelajaran kooperatif siswa akan lebih mudah memahami dan menemukan pemecahan suatu masalah dengan berdiskusi dengan teman-temannya. Pada pembelajaran ini para siswa akan lebih aktif terlibat dalam kegiatan belajar dan meningkatkan interaksi diantara siswa dengan siswa dan siswa dengan guru. Lima elemen dasar dalam pembelajaran kooperatif adalah saling ketergantungan positif, tanggung jawab perseorangan, tatap muka, komunikasi antar anggota, dan evaluasi proses kelompok.

Model pembelajaran kooperatif Group Investigation adalah penemuan yang dilakukan secara berkelompok dengan siswa secara berkelompok mengalami dan melakukan percobaan/latihan dengan aktif yang memungkinkannya menemukan prinsip. Langkah-langkah pembelajaran MPKGI adalah sebagai berikut.

1. Guru membagi kelas dalam beberapa kelompok heterogen

2. Guru menjelaskan maksud pembelajaran dan tugas kelompok

3. Guru memanggil ketua-ketua kelompok untuk memilih satu materi tugas, sehingga satu kelompok mendapat tugas satu materi/tugas yang berbeda dengan kelompok lain

4. Masing-masing kelompok membahas materi yang sudah ada secara kooperatif serta berisi penemuan

5. Setelah selesai diskusi, lewat juru bicara, ketua menyampaikan hasil pembahasan kelompok

6. Guru memberikan penjelasan singkat sekaligus memberi kesimpulan

7. Evaluasi

8. Penutup

Menurut Herman Hudoyo (2001), matematika melukiskan suatu kumpulan sistem matematika, dimana setiap bagian dari sistem ini merupakan struktur yang bersifat deduktif. Suatu sistem deduktif terdiri dari unsur-unsur yang tidak didefinisikan, unsur-unsur yang didefinisikan, aksioma-aksioma, dan teorema-teorema. Hakikat matematika berkenaan dengan ide-ide, strukturstruktur, dan hubungan-hubungan yang diatur menurut urutan logik. Suatu kebenaran matematik dikembangkan berdasarkan pada alasan logik, namun kerja matematik antara lain mengobservasi, menebak, menduga, membuat dan mengetes hipotesis, mencari analogi, melakukan koneksi dan komunikasi, membuat representasi, membuat generalisasi, membuktikan teorema, dan memecahkan masalah.

Beyer (dalam Santoso, 2006) mengatakan bahwa kemampuan berpikir kritis meliputi beberapa kemampuan sebagai berikut: (1) menentukan kredibilitas suatu sumber, (2) membedakan antara yang relevan dari yang tidak relevan, membedakan fakta dari penilaian, (4) mengidentifikasi dan mengevaluasi asumsi yang tidak terucapka, (5) mengidentifikasi bias yang ada, (6) mengidentifikasi sudut pandang, dan 
(7) mengevaluasi bukti yang ditawarkan untuk mendukung pengakuan.

Krulik \& Rudnick (dalam Siswono, 2004) mengemukakan bahwa yang termasuk berpikir kritis dalam matematika adalah berpikir yang menguji, mempertanyakan, menghubungkan, mengevaluasi semua aspek yang ada dalam suatu situasi ataupun suatu masalah. Demikian juga dari suatu data ataupun informasi siswa dapat membuat kesimpulan yang tepat dan benar sekaligus melihat adanya kontradiksi ataupun ada tidaknya konsistensi atau kejanggalan dalam informasi tersebut. Jadi dalam berpikir kritis siswa menganalisis dan merefleksikan hasil berpikirnya. Siswa yang berpikir kritis selalu peka terhadap informasi atau situasi yang sedang dihadapinya, dan cenderung bereaksi terhadap situasi atau informasi tersebut.

Bakat, minat dan intelegensi adalah faktor yang mempengaruhi proses dan hasil belajar siswa. Bakat siswa walaupun dibawa dan telah terbentuk sejak lahir dimungkinkan manjadi suatu kecakapan, pengetahuan dan keterampilan khusus bila adanya pengembangan dan latihan tertentu serta dipengaruhi oleh faktor keluarga, lingkungan, dan nilainilai yang ada lingkungan siswa. Siswa bukannya tidak berbakat pada suatu bidang, tetapi kecenderungan yang terjadi siswa belum dapat menggali dan memaksimalkan fungsi dari kedua belahan otak, namun lebih banyak membatasi fungsi dari masing-masing belahan otak tersebut.

Bakat numerik yang dimiliki siswa dapat dibedakan menjadi dua, yaitu: bakat numerik tinggi dan bakat numerik rendah. Siswa yang memiliki bakat numerik tinggi akan memiliki karakter-karakter seperti: (1) yakin akan kemampuannya untuk mengatasi masalah, (2) merasa setara dengan orang lain, (3) lebih mudah dan cepat dalam melakukan perhitunganperhitungan berupa angka, (4) mampu memperbaiki dirinya dan berusaha untuk mengubah diri menjadi lebih baik, dan (5) mempunyai tingkat penguasaan materi/konsep lebih tinggi. Dalam pembelajaran, siswa yang memiliki bakat numerik tinggi selalu ingin mengemukakan gagasangagasan yang dapat digunakan untuk memperbaiki gagasan yang dirasakan tidak sesuai dengan konsep yang benar. Siswa yang memiliki bakat numerik tinggi yakin dengan kemampuannya untuk mengubah gagasan yang keliru menjadi konsep yang benar tanpa harus meniru orang lain. Siswa yang memiliki bakat numerik rendah akan memiliki kepercayaan diri yang rendah terhadap kemampuannya dalam menyelesaikan tugas-tugasnya.

Penerapan model pembelajaran yang berbeda juga akan memberikan lingkungan belajar/suasana belajar, keterampilan berpikir dan interaksi antar siswa yang berbeda pula. Siswa dalam model pembelajaran kooperatif tipe Gl dituntut bertanggung jawab atas pendidikan yang mereka jalani, serta diarahkan untuk tidak terlalu tergantung pada guru. Model pembelajaran kooperatif Gl membentuk siswa mandiri yang dapat melanjutkan proses belajar pada kehidupan dan karir yang akan mereka jalani. Seorang guru lebih berperan sebagai fasilitator atau tutor dan guru tidak menyajikan konsep-konsep dalam pembelajaran, namun konsepkonsep akan dicari siswa sendiri melalui permasalahan yang diberikan. Permasalahan yang disajikan dalam pembelajaran adalah permasalahan riil yakni permasalahan yang ada di lingkungan siswa. Model pembelajaran kooperatif Gl adalah suatu model 
pembelajaran yang menggunakan masalah dunia nyata sebagai suatu konteks bagi siswa untuk belajar tentang kemampuan berpikir dan kemampuan pemecahan masalah, serta kemampuan untuk memperoleh pengetahuan serta konsep yang essensial dari suatu materi pelajaran.

Tujuan yang ingin dicapai melalui penelitian ini adalah untuk menganalisis (1) perbedaan kemampuan berpikir kritis antara siswa yang mengikuti model pembelajaran kooperatif Group Investigation dengan siswa yang mengikuti model pembelajaran langsung. (2) pengaruh interaksi antara model pembelajaran dengan bakat numerik siswa terhadap kemampuan berpikir kritis siswa. (3) perbedaan kemampuan berpikir kritis antara siswa yang mengikuti model pembelajaran kooperatif Group Investigation dengan siswa yang mengikuti model pembelajaran langsung. (4) perbedaan kemampuan berpikir kritis antara siswa yang mengikuti model pembelajaran kooperatif Group Investigation dengan siswa yang mengikuti model pembelajaran langsung.

Penelitian Mawa (2009) dalam tesisnya yang berjudul pengaruh model pembelajaran kooperatif tipe team assisted individualization (TAI) Disertai metode eksplorasi terhadap prestasi belajar matematika ditinjau dari bakat numerik dan adversity quotient siswa kelas VIII SMP, menyimpulkan: (1) ada perbedaan prestasi belajar matematika antara siswa yang mengikuti model pembelajaran kooperatif tipe TAI disertai metode eksplorasi dengan siswa yang mengikuti pembelajaran konvensional, (2) ada perbedaan prestasi belajar matematika antara siswa yang mengikuti model pembelajaran kooperatif tipe TAI disertai metode eksplorasi dengan siswa yang mengikuti pembelajaran konvensiona setelah bakat numerik dikendalikan, (3) ada perbedaan prestasi belajar matematika antara siswa yang mengikuti model pembelajaran kooperatif tipe TAI disertai metode eksplorasi dengan siswa yang mengikuti pembelajaran konvensiona setelah kovariabel adversity quotient dikendalikan, (4) ada perbedaan prestasi belajar matematika antara siswa yang mengikuti model pembelajaran kooperatif tipe TAl disertai metode eksplorasi dengan siswa yang mengikuti pembelajaran konvensionaal setelah bakat numerik dan adversity quotient dikendalikan.

Penelitian Ngurah (2008) dalam tesisnya yang berjudul pengaruh pendekatan pembelajaran Heuristik Vee dan Algoritmik terhadap prestasi belajar matematika ditinjau dari bakat numeri siswa SMP, menyimpulkan: (1) secara keseluruhan prestasi belajar matematika siswa yang mengikuti pendekatan pembelajaran heuristik vee berbeda dengan siswa yang mengikuti pendekatan pembelajaran algoritmik, (2) prestasi belajar matematika siswa yang memiliki bakat numerik tinggi yang mengikuti pendekatan pembelajaran heuristik vee lebih baik dari siswa yang memiliki bakat numerik tinggi yang mengikuti pendekatan pembelajaran algoritmik, (3) prestasi belajar matematika siswa yang memiliki bakat numerik rendah yang mengikuti pendekatan pembelajaran algoritmik lebih baik dari siswa yang memiliki bakat numerik rendah yang mengikuti pendekatan pembelajaran heuristik vee, (4) terdapat pengaruh interaksi antara pendekatan pembelajaran dengan bakat numerik terhadap prestasi belajar matematika.

Penelitian Wulandari
(2011)


pengembangan perangkat pembelajaran matematika realistik berbantuan TIK dalam upaya meningkatkan aktivitas dan prestasi belajar matematika siswa kelas XI SMK, menyimpulkan: (1) penelitian telah berhasil mengembangkan perangkat pembelajaran matematika realistik, di mana proses pengembangannya telah mengikuti prosedur pengembangan Plomp, (2) perangkat pembelajaran yang berhasil dikembangkan dalam penelitian telah memenuhi kriteria kualitas perangkat pembelajaran aspek validitas, kepraktisan, dan keefektifan.

Penelitian Juniantari (2011) dalam tesisnya yang berjudul pengembangan perangkat pembelajaran matematika realistik dengan setting model kooperatif MURDER bagi siswa SMP kelas VII, menyimpulkan: (1) pengembangan perangkat pembelajaran matematika realistik dengan setting model kooperatif MURDER pada standar kompetensi memahami konsep segitiga dan segiempat serta menentukan ukurannya bagi siswa SMP kelas VII dalam penelitian melalui empat tahap yaitu; investigasi awal, desain, realisasi, serta tes, evaluasi, dan revisi sampai akhirnya ditemukan suatu prototipe final dari perangkat pembelajaran yang siap untuk diimplementasikan, (2) perangkat pembelajaran matematika realistik dengan setting model kooperatif MURDER pada standar kompetensi memahami konsep segitiga dan segiempat serta menentukan ukurannya bagi siswa SMP kelas VII dalam penelitian telah memenuhi kriteria validitas, kepraktisan, dan efektifitas yang diharapkan.

Penelitian tentang berpikir kritis dilakukan oleh Melvile Jones (1999); Redhana (2002); Elizabeth Murphy (2004); Arnyana (2004); Sadia dan
Suma (2006); Warpala (2006). Melville Jones mengemukakan bahwa pembelajaran yang berorientasi pada peningkatan keterampilan berpikir kritis akan membawa siswa terhadap penguasaan konteks pembelajaran. Hasil penelitian Redhana (2002) mengungkapkan bahwa telah terjadi peningkatan keterampilan berpikir kritis dengan menerapkan pembelajaran kooperatif yang dipandu strategi pemecahan masalah. Elizabeth Murphy menyatakan bahwa pembelajaran yang memperhatikan keterampilan berpikir kritis dapat membangun empat pemikiran diantaranya review, síntesis, análisis, dan evaluasi. Pembelajaran tersebut memberikan peningkatan yang signifikan dibandingkan pembelajaran konvensional. Lebih lanjut, hasil penelitian Arnyana (2004) menyatakan bahwa strategi kooperatif Gl memberikan pengaruh yang lebih baik dalam meningkatkan kemampuan berpikir kritis siswa dibandingkan dengan strategi kooperatif STAD. Menurut Sadia dan Suma (2006), Penerapan Model Pembelajaran Learning Cycle dan problem Based Learning dan kemampuan mengembangkan kemampuan berpikir formal siswa. Hal ini juga dikaitkan dengan hasil penelitian Warpala (2006) yang menyatakan bahwa strategi kooperatif Gl dan STAD memberikan dampak yang berbeda secara signifikan terhadap kemampuan berpikir kritis, tipe Gl lebih efektif digunakan untuk pencapaian kemampuan berpikir kritis dibandingkan STAD.

Penelitian yang dilakukan Sogog, dkk (1995), menyatakan kemampuan numerik memiliki kontribusi terhadap penguasaan matematika, kemampuan numerik merupakan faktor penyebab kesulitan belajar matematika. Penelitian ini menemukan bahwa 
terdapat hubungan yang positif dan signifikan antara kemampuan penalaran, kemampuan verbal, dan kemampuan numerik terhadap prestasi belajar matematika. Jadi bakat numerik adalah kemampuan untuk melakukan operasi hitung aritmatika secara manual dengan tepat dan akurat.

\section{METODE PENELITIAN}

Penelitian ini merupakan penelitian eksperimen semu (quasi experiment). Desain eksperimen ini dipilih karena eksperimen dilakukan disuatu kelas tertentu dengan siswa yang telah ada dan sebagaimana adanya. Dalam menentukan subyek penelitian untuk kelompok eksperimen maupun kelompok kontrol tidak memungkinkan mengubah kelas yang ada. Randomosasi individu tidak bisa dilakukan, sehingga dalam menetapkan kelompok eksperimen dan kelompok kontrol dilakukan secara acak terhadap kelas yang ada (randomisasi dari kelas-kelas yang utuh). Dengan demikian dalam penelitian ini tidak semua variabel internal yang mempengaruhi hasil penelitian dapat dikontrol secara ketat. Penelitian ini menggunakan two way pretest-posttest non-equivalent control group design.

Rancangan analisis data yang digunakan dalam penelitian ini adalah rancangan faktorial $2 \times 2$ dengan matriks $A B$. Faktor-faktornya terdiri atas dua model pembelajaran, yaitu: model pembelajaran kooperatif Group Investigation (MPKGI) yang akan diberlakukan pada kelompok eksperimen dan model pembelajaran langsung (MPL) yang akan diberlakukan pada kelompok kontrol. Faktor pemilahnya adalah bakat numerik siswa: bakat numerik tinggi dan bakat numerik rendah. Kategori bakat numerik siswa ditentukan berdasarkan perolehan skor siswa dari tes bakat numerik.

Populasi dari penelitian ini adalah kelas XI IA SMAN 2 Semarapura tahun pelajaran $2013 / 2014$ yang terdiri dari enam kelas yaitu XI IA1, XI IA2, XI IA3, XI IA4, XI IA5, XI IA6. Banyaknya populasi adalah 171 orang. Kurikulum yang digunakan pada kelas XI tahun pelajaran 2013/2014 adalah Kurikulum Tingkat Satuan Pendidikan (KTSP), seluruh siswa kelas XI IA mendapat pelajaran matematika sebanyak 6 jam pelajaran perminggu. Seluruh populasi yang akan diteliti memiliki kemampuan terkait dengan bilangan yang disebut bakat numerik dan memiliki kemampuan berpikir kritis terhadap pelajaran Matematika.

Sampel adalah bagian dari suatu populasi (Sugiyono, 2009). Setiap anggota populasi mendapat peluang yang sama untuk menjadi anggota sampel. Karena dalam penelitian ini anggota populasi terdistribusi pada kelas yang utuh, maka pemilihan sampel dilakukan pada kelas-kelas tersebut. Hal ini dilakukan karena tidak mungkin untuk melakukan pengacakan terhadap individuindividu. Dalam penelitian ini sampel diambil dengan teknik random sampling. Teknik random dilakukan pada kelas-kelas utuh yang merupakan subjek dalam penelitian ini. Langkah-langkah untuk menentukan sampel yang nantinya akan dijadikan sebagai kelompok eksperimen dan kelompok kontrol adalah sebagai berikut. (1) Melakukan Uji Kesetaraan Kelas. (2) Melakukan Pengambilan Sampel. (3) Memilah Kelompok Eksperimen dan Kontrol. (4) Memilih Kelompok Bakat Numerik Tinggi dan Rendah.

Dalam penelitian ini terdapat tiga variabel yang terdiri dari satu variabel 
bebas, satu variabel moderator, dan satu variabel terikat. Variabel bebas adalah model pembelajaran sebagai variabel perlakuan, variabel moderator adalah bakat numerik, dan variabel terikat adalah kemampuan berpikir kritis siswa. Variabel bebas terdiri dari dua dimensi, yaitu model pembelajaran kooperatif GI (MPKGI) untuk kelompok eksperimen, dan model pembelajaran langsung (MPL) untuk kelompok kontrol. Variabel moderator terdiri dari dua dimensi, yaitu bakat numerik tinggi (BNT) dan bakat numerik rendah (BNR).

Untuk mengetahui kemampuan berpikir kritis awal siswa, maka diberikan pretest pada awal eksperimen. Agar hasil belajar yang berupa kemampuan berpikir kritis siswa dalam pelajaran matematika, khususnya pada materi Trigonometri dapat dinyatakan hasil dari perlakuan eksperimen dan dapat digeneralisasi, maka perlu dilakukan pengontrolan validitas internal. Dalam penelitian ini variabel yang dapat dikontrol diantaranya, yaitu: (1) jadwal belajar disusun pada jam yang sama (hari berbeda) atau pada hari yang sama tetapi waktunya berdekatan, (2) proses pembelajaran dilakukan oleh guru yang sama, (3) siswa tidak diberitahu jika dijadikan sebagai subjek penelitian, (4) pelaksanan pretest dilakukan pada hari dan jam yang sama, (5) pelaksanaan posttest dilakukan pada hari dan jam yang sama untuk semua kelompok, (6) pengambilan sampel dilakukan secara acak melalui randomisasi kelas-kelas yang utuh, dan (7) penelitian tidak dilakukan dalam waktu yang terlalu lama tujuanya untuk menghindari kejenuhan siswa.

Data yang akan dikumpulkan dalam penelitian ini meliputi bakat numerik siswa dan kemampuan berpikir kritis siswa pada mata pelajaran matematika materi Trigonometri yang terdiri dari nilai pretest dan posttest. Metode yang dipergunakan untuk mengumpulkan data adalah menggunakan test. Untuk mengumpulkan data mengenai bakat numerik digunakan tes bakat numerik, sedangkan data mengenai kemampuan berpikir kritis digunakan tes kemampuan berpikir kritis dalam bentuk tes uraian (konten) dan tes pilihan ganda.

Tes bakat numerik terdiri dari aspek operasi hitung aljabar, operasi hitung yang melibatkan deret bilangan, dan operasi hitung yang melibatkan soal-soal cerita. Tes ini berupa tes pilihan ganda yang terdiri atas 40 item soal dengan lima pilihan jawaban. Skor untuk setiap item soal adalah 1 untuk jawaban benar dan 0 untuk jawaban salah, sehingga skor maksimum yang dapat diperoleh masing-masing subjek penelitian adalah 40 .

Tes kemampuan berpikir kritis yang dikembangkan terdiri dari dua tipe. Tipe pertama menggunakan bentuk test uraian yang terdiri dari 5 item dan tipe kedua menggunakan bentuk tes pilihan ganda yang terdiri dari 25 item. Dengan menggunakan bentuk tes uraian, siswa tidak hanya sekedar menjawab, melainkan harus menggunakan semua kemampuan berpikirnya untuk mengungkapkan alasan jawaban mereka sehingga siswa tidak hanya sekedar memberikan jawaban yang dianggap benar. Siswa dalam menjawab tes ini dituntut untuk memberikan jawaban yang akurat dan komprehensif.

Dalam penelitian ini kemampuan dan indikator berpikir kritis yang digunakan adalah kemampuan berpikir kritis menurut California Academic Press (1990) yang dimodifikasi sesuai dengan karakteristik mata pelajaran matematika. Tes kemampuan berpikir 
kritis dikelompokkan menjadi dua yaitu tes uraian dan tes pilihan ganda. Tes ini terdiri dari 5 item soal uraian dan 25 item soal pilihan ganda dengan lima pilihan jawaban kisi-kisi tes kemampuan berpikir kritis.

\section{HASIL PENELITIAN DAN PEMBAHASAN}

Hasil penelitian memaparkan tiga hal pokok, yaitu (1) deskripsi umum hasil penelitian, (2) analisis data pengujian hipotesis, dan (3) profil interaksi antara model pembelajaran dengan bakat numerik dan kemampuan berpikir kritis siswa. Pembahasan hasil penelitian, memaparkan tiga hal pokok, (1) pengaruh model pembelajaran MPKGI dengan MPL dalam bakat numerik dan kemampuan berpikir kritis siswa, (2) pengaruh model pembelajaran MPKGI dengan MPL dalam pencapaian kemampuan berpikir kritis, pengaruh model pembelajaran MPKGI dengan MPL dalam pencapaian bakat numerik siswa.

\section{Hasil}

Hasil penelitian memaparkan tiga hal pokok, yaitu (1) deskripsi umum hasil penelitian, (2) analisis data pengujian hipotesis, dan pembahasan hasil penelitian.

Data hasil penelitian berupa skor tes hasil kemampuan berpikir kritis yang terdiri atas skor pretest, posttest, dan skor gain yang dinormalisasi ( $\mathrm{N}$ gain) dari keseluruhan unit analisis yang terdistribusi pada masing-masing kelompok perlakuan. Skor pretest dan posttest tes hasil kemampuan berpikir kritis dalam bentuk tes uraian dan tes pilihan ganda yang berkisar antara 0 sampai dengan 45 . Berdasarkan skor pretest dan posttest diperoleh skor gain yang dinormalisasi ( $\mathrm{N}$-gain) yang dihitung dengan menggunakan rumus
Hake (1999). Di samping itu, juga digunakan tes bakat numerik. Hasil tes bakat numerik digunakan untuk menentukan kelompok siswa yang memiliki bakat numerik tinggi (33\% kelompok atas) dan kelompok siswa yang memiliki bakat numerik rendah (33\% kelompok bawah). Siswa lainnya yang berada pada bagian tengah, mereka tetap mengikuti proses pembelajaran seperti biasa pada kelasnya masing-masing.

Dari penelitian ditemukan skor rata-rata dan standar deviasi kemampuan berpikir kritis siswa, ditemukan $\mathrm{N}$-gain kemampuan berpikir kritis siswa untuk MPKGI dan MPL. Dengan membandingkan skor kemampuan berpikir kritis siswa diketahui bahwa, pada MPKGI dengan BNT yang berkategori tinggi sebanyak 9 orang $(60 \%)$, berkategori sedang sebanyak 6 orang $(40 \%)$ dan berkategori rendah sebanyak 0 orang $(0 \%)$ sedangkan pada kelompok MPKGI dengan BNR yang berkategori tinggi sebanyak 4 orang (26,67\%), bertegori sedang sebanyak 11 orang $(73,33 \%)$ dan berkategori rendah sebanyak 0 orang (0\%). Pada kelompok MPL dengan BNT kategori tinggi sebanyak 2 orang (13,33\%), berkategori sedang sebanyak 13 orang $(86,67 \%)$ dan kategori rendah sebanyak 0 orang $(0 \%)$ sedangkan pada kelompok MPL dengan BNR yang berkategori tinggi sebanyak 1 orang $(6,67 \%)$, kategori sedang sebanyak 13 orang $(86,67 \%)$ dan kategori rendah sebanyak 1 orang $(6,67 \%)$.

Secara keseluruhan berdasarkan kelompok model pembelajaran MPKGI menunjukkan rata-rata kemampuan berpikir kritis lebih tinggi $(M=0,677)$ dibandingkan kelompok MPL $(\mathrm{M}=$ 0,570 ), secara keseluruhan jika dilihat dari aspek bakat numerik, kelompok BNT memiliki skor rata-rata 
kemampuan berpikir kritis lebih tinggi $(\mathrm{M}=0,674)$ dibandingkan kelompok $\operatorname{BNR}(M=0,573)$.

Berdasarkan kriteria $\mathrm{N}$-gain yang dinormalisasi secara keseluruhan kelompok MPKGI menunjukkan skor $\mathrm{N}$-gain yang lebih baik dengan kategori tinggi sebanyak 13 orang kategori sedang 17 orang dan kategori rendah 0 , dibandingkan kelompok MPL kategori tinggi sebanyak 3 orang, kategori sedang sebanyak 26 orang dan kategori rendah sebanyak 1 orang. Secara keseluruhan bila dilihat dari aspek bakat numerik skor $\mathrm{N}$-gain kelompok BNT sebanyak 11 orang, kategori sedang sebanyak 19 orang dan kategori rendah 0 orang dibandingkan kelompok BNR sebanyak 5 orang, kategori sedang sebanyak 24 orang dan kategori rendah sebanyak 1 orang.

Secara keseluruhan berdasarkan kelompok model pembelajaran dilihat dari skor pencapaian kemampuan berpikir kritis materi peluang kelompok MPKGI menunjukkan skor rata-rata lebih baik dengan kategori sedang pada semua indikator dibandingkan dengan kelompok langsung terdapat pencapaian indikator dengan kategori rendah pada satu indikator. Secara keseluruhan jika dilihat dari aspek bakat numerik, kelompok bakat numerik tinggi menunjukkan skor ratarata lebih baik dibandingkan dengan bakat numerik rendah.

Skor kemampuan berpikir kritis pada siswa yang mengikuti MPKGI dengan bakat numerik tinggi kategori sedang terdapat pada indikator interpretasi, evaluasi, inferensi dan eksplanasi, sedangkan kategori rendah terdapat pada indikator analisis. Pada kelompok siswa yang mengikuti MPKGI dengan bakat numerik rendah kategori sedang terdapat pada indikator interpretasi, evaluasi, inferensi dan eksplanasi, sedangkan kategori rendah terdapat pada indikator analisis. Pada kelompok siswa yang mengikuti MPL dengan bakat numerik tinggi kategori sedang terdapat pada indikator evaluasi, sedangkan kategori rendah terdapat pada indikator interpretasi, analisis, inferensi dan eksplanasi. Dan untuk kelompok siswa yang mengikuti MPL dengan bakat numerik rendah kategori sedang terdapat pada indikator evaluasi, sedangkan kategori rendah terdapat pada indikator interpretasi, analisis.inferensi dan eksplanasi.

Kategori gain yang dinormalisasi pada kelompok siswa yang memiliki bakat numerik tinggi yang berkategori tinggi sebanyak 11 orang (36,67\%), berkategori sedang sebanyak 19 orang $(63,33 \%)$ dan yang berkategori rendah sebanyak 0 orang $(0 \%)$, sedangkan pada kelompok siswa yang memiliki bakat numerik rendah yang berkategori tinggi sebanyak 5 orang $(16,67 \%)$, berkategori sedang sebanyak 24 orang (80\%), dan berkategori rendah sebanyak 1 orang $(3,33 \%)$.

Kategori gain yang dinormalisasi pada kelompok siswa yang memiliki bakat numerik tinggi yang mengikuti pembelajaran dengan menggunakan MPKGI yang berketegori tinggi sebanyak 9 orang $(60 \%)$, berkategori sedang sebanyak 6 orang (40\%), dan berkategori rendah sebanyak 0 orang $(0 \%)$. Sedangkan kelompok siswa yang mengikuti pembelajaran dengan menggunakan MPL berkategori tinggi sebanyak 2 orang $(13,33 \%)$, berkategori sedang sebanyak 13 orang $(86,67 \%)$, dan berkategori rendah sebanyak 0 orang $(0 \%)$.

Perbandingan skor rata-rata pretest untuk kelompok eksperimen (MPKGl) 18,4 dari skor ideal 45, dan kelas kontrol (MPL) 18,23 dari skor ideal 45 , sedangkan perbandingan 
skor rata-rata posttest kelompok eksperimen sebesar 39,77 dari skor ideal 45 dan kelompok kontrol sebesar 35,37 dari skor ideal 45. Skor rata-rata gain yang dinormalisasi (Ngain) untuk kelompok eksperimen sebesar 0,675 atau 67,5 dengan kategori sedang dan kelompok kontrol sebesar 0,535 atau 53,5 dengan kategori sedang.

Perbandingan rata-rata skor pretest untuk kelompok bakat numerik tinggi sebesar 18,74 dari skor ideal 45, dan kelompok bakat numerik rendah sebesar 18,6 dari skor ideal 45, sedangkan skor rata-rata posttes pada kelompok bakat numerik tinggi sebesar 39,77 dari skor ideal 45 dan kelompok bakat numerik rendah sebesar 36,57 dari skor ideal 45. Skor rata-rata gain yang dinormalisasi $(\mathrm{N}$ gain) untuk kelompok bakat numerik tinggi sebesar 0,67 atau 67 dengan kategori sedang dan kelompok bakat numerik rendah sebesar 0,57 atau 57 dengan kategori sedang.

Perbandingan skor rata-rata pretest untuk kelompok eksperimen (MPKGI-BNT) sebesar 18,87 dari skor ideal 45, dan kelompok kontrol (MPLBNT) sebesar 18,53 dari skor ideal 45, sedangkan perbandingan skor ratarata posttes pada kelompok eksperimen sebesar 42,60 dari skor ideal 45 dan kelas kontrol sebesar 36,53 dari skor ideal 45. Skor rata-rata gain yang dinormalisasi ( $\mathrm{N}$-gain) untuk kelompok eksperimen sebesar 0,76 atau 76 dengan kategori tinggi dan untuk kelompok kontrol sebesar 0,56 atau 56 dengan kategori sedang.

Perbandingan skor rata-rata pretest untuk kelompok eksperimen (MPKGI-BNR) sebesar 17,93 dari skor ideal 45, dan kelompok kontrol (MPLBNR) sebesar 17,93 dari skor ideal 45, sedangkan perbandingan skor ratarata posttest untuk kelompok eksperimen sebesar 36,93 dari skor ideal 45 dan kelompok kontrol sebesar 34,2 dari skor ideal 45. Skor rata-rata gain yang dinormalisasi ( $\mathrm{N}$-gain) untuk kelompok eksperimen sebesar 0,59 atau 59 dengan kategori sedang dan kelompok kontrol sebesar 0,51 atau 51 dengan kategori sedang.

\section{Pembahasan}

$\begin{array}{ccc}\text { Hasil uji } & \begin{array}{c}\text { hipotesis } \\ \text { bahwa }\end{array} & \begin{array}{c}\text { pertama } \\ \text { terdapat }\end{array}\end{array}$ perbedaan kemampuan berpikir kritis antara siswa yang mengikuti model pembelajaran kooperatif Group Investigation (MPKGI) dengan siswa yang mengikuti pembelajaran langsung. Temuan ini sangat logis karena MPKGl mendorong siswa membangun sendiri pengetahuannya. Siswa terlibat secara aktif dalam model pembelajaran kooperatif tipe GI. Siswa dalam model pembelajaran kooperatif tipe Gl dituntut bertanggung jawab atas proses pembelajaran yang dijalani, serta diarahkan untuk tidak terlalu tergantung pada guru. Model pembelajaran kooperatif tipe GI membentuk siswa mandiri karena guru lebih berperan sebagai fasilitator. Guru tidak menyajikan konsep-konsep dalam pembelajaran, namun konsep dicari sendiri oleh siswa melalui permasalahan yang diberikan.

Terdapat pengaruh interaksi antara model pembelajaran dengan bakat numerik siswa terhadap kemampuan berpikir kritis siswa. Temuan ini sangat masuk akal, karena bakat numerik sangat menentukan kemampuan seseorang dalam perhitungan-perhitungan meliputi operasi penjumlahan, pengurangan, perkalian, pembagaian, perpangkatan, maupun penarikan akar. Bakat numerik yang dimiliki oleh siswa sangat berpengaruh terhadap proses pembelajaran. Di samping bakat alami 
yang dimiliki siswa, bakat numerik ini juga diperoleh melalui latihan.

Siswa yang memiliki bakat numerik tinggi, terdapat perbedaan kemampuan berpikir kritis antara siswa yang mengikuti model pembelajaran kooperatif Group Investigation dengan siswa yang mengikuti pembelajaran langsung. Temuan tersebut sesuai dengan teori yang ada dan sesuai pula dengan temuan peneliti lain. Tiap jenis bakat numerik dari siswa memiliki cara tersendiri dalam memandang suatu objek, penerimaan imformasi, mengingat, berpikir, berinteraksi, dan menggunakan strategi dalam melakukan tugas dan memecahkan masalah. Dengan adanya variasi tersebut tentunya kemampuan berpikir kritis setiap siswa juga akan berbeda. Siswa yang memiliki bakat numerik tinggi akan lebih tertantang dalam belajar dengan model kooperatif tipe GI. Mereka cenderung mengkontruksi konsep-konsep materi sehingga kemampuan berpikir kritisnya berkembang. Sebaliknya, siswa yang memiliki kemampuan numerik tinggi akan merasa bosan jika terus dituangi konsep-konsep yang sudah jadi. Akibatnya kemampuan berpikir kritis mereka tidak berkembang. Jadi wajar kalau untuk siswa yang memiliki bakat numerik tinggi, terdapat perbedaan kemampuan berpikir kritis antara siswa yang mengikuti model pembelajaran kooperatif Group Investigation dengan siswa yang mengikuti pembelajaran langsung.

Siswa yang memiliki bakat numerik rendah, tidak terdapat perbedaan kemampuan berpikir kritis antara siswa yang mengikuti model pembelajaran kooperatif Group Investigation dengan siswa yang mengikuti pembelajaran langsung. Temuan tersebut sangat sesuai dengan teori yang ada dan sesuai pula dengan temuan peneliti lain. Siswa yang memiliki bakat numerik rendah cenderung kurang mampu menalar. Model pembelajaran apapun diterapkan, meraka tetap kurang mampu menalar karena penalaran sangat dipengaruhi kemampuan numerik. Jika siswa kurang mampu menalar, maka kemampuan berpikir kritisnya juga kurang. Akibatnya kemampuan berpikir kritis mereka tidak berkembang, baik jika difasilitasi dengan pembelajaran kooperatif tipe $\mathrm{Gi}$ maupun dengan pembelajarn langsung Jadi wajar kalau untuk siswa yang memiliki bakat numerik rendah, tidak terdapat perbedaan kemampuan berpikir kritis antara siswa yang mengikuti model pembelajaran kooperatif Group Investigation dengan siswa yang mengikuti pembelajaran langsung.

\section{PENUTUP}

\section{Simpulan}

Berdasarkan hasil analisis data dan pembahasan yang telah diuraikan pada bab IV dapat dirumuskan simpulan sebagai berikut.

1) Terdapat perbedaan pengaruh antara MPKGI dan MPL terhadap kemampuan berpikir kritis siswa pada pelajaran Matematika. Kemampuan berpikir kritis kelompok siswa yang mengikuti pembelajaran dengan menggunakan MPKGI lebih baik dibandingkan dengan kelompok siswa yang mengikuti pembelajaran dengan menggunakan MPL.

2) Terdapat perbedaan pengaruh antara siswa yang memiliki BNT dengan siswa yang memiliki BNR terhadap kemampuan berpikir kritis pada pelajaran Matematika. Kemampuan berpikir kritis kelompok siswa yang memiliki BNT lebih baik 
dibandingkan dengan kelompok siswa yang memiliki BNR.

3) Terdapat pengaruh interaksi antara model pembelajaran dan bakat numerik terhadap kemampuan berpikir kritis siswa pada pelajaran Matematika.

4) Terdapat perbedaan kemampuan berpikir kritis antara kelompok siswa yang mengikuti pembelajaran dengan menggunakan MPKGI dan kelompok siswa yang mengikuti pembelajaran dengan menggunakan MPL, pada kelompok siswa yang memiliki BNT. Kemampuan berpikir kritis pada kelompok siswa yang memiliki BNT lebih baik jika mengikuti pembelajaran dengan menggunakan MPKGI dibandingkan dengan jika mengikuti pembelajaran dengan menggunakan MPL.

Tidak terdapat perbedaan kemampuan berpikir kritis antara kelompok siswa yang mengikuti pembelajaran dengan menggunakan MPKGI dan kelompok siswa yang mengikuti pembelajaran dengan menggunakan MPL, pada kelompok siswa yang memiliki BNR. Kemampuan berpikir kritis pada kelompok siswa yang memiliki BNR tidak berbeda jika mengikuti pembelajaran dengan menggunakan MPKGI dibandingkan dengan jika mengikuti pembelajaran dengan menggunakan MPL.

\section{Saran}

Berdasarkan temuan-temuan dan simpulan pada penelitian ini, maka sebagai tindak lanjut dari penelitian ini dikemukakan beberapa saran sebagai berikut.

1) Dari hasil penelitian menunjukkan bahwa kemampuan berpikir kritis siswa yang mengikuti MPKGI lebih baik daripada siswa yang mengikuti MPL, dapat disarankan MPKGI perlu diperkenalkan kepada guru Matematika sebagai alternatif model dalam pembelajaran matematika. Model pembelajaran kooperatif tipe Gl telah terbukti dapat meningkatkan kemampuan berpikir kritis siswa.

2) Berdasarkan hasil temuan dalam penelitian ini, model pembelajaran yang dipilih untuk memfasilitasi siswa dalam belajar sebaiknya disesuaikan dengan karaktristik siswa. MPKGI cocok diterapkan untuk memfasilitasi siswa belajar baik pada siswa yang memiliki bakat numerik tinggi maupun pada siswa yang memiliki bakat numerik rendah, karena berdasarkan hasil penelitian sudah terbukti dapat meningkatkan kemampuan berpkir kritis terhadap materi pelajaran.

3) Diperlukan kesabaran guru dalam membimbing siswa dan secara terus menerus memberikan motivasi kepada siswa jika menerapkan MPKGI pada siswa yang memiliki bakat numerik tinggi.

4) Bagi lembaga pendidikan yang mengembangkan misi untuk mendidik calon-calon guru mata pelajaran matematika, hendaknya secara terus menerus memperkenalkan dan melatih siswa untuk menggunakan MPKGI maupun model lainnya dalam usaha mencetak calon-calon pendidik yang handal.

\section{DAFTAR RUJUKAN}

Istini, R. R. \& Redhana, I W 2001. Penerapan strategi penemuan terbimbing untuk meningkatkan kemampuan berpikir kritis siswa kelas $\|_{1}$ SMUN 4 Singaraja tahun 
ajaran 2000/2001. Laporan penelitian (tidak diterbitkan). Program studi Pendidikan Kimia, IKIP Negeri Singaraja.

Juniantari, M. 2011. Pengembangan Perangkat Pembelajaran Matematika Realistik Dengan Setting Model Kooperatif MURDER Bagi Siswa SMP Kelas VII. Tesis (tidak diterbitkan). Program Studi Pendidikan Matematika, Program Pascasarjana, Undiksha.

Mawa, I W. 2009. Pengaruh Model Pembelajaran Kooperatif Tipe Team Assisted Individualization (TAl) Berbasis Metode Eksplorasi Terhadap Prestasi Belajar Matematika Ditinjau dari Bakat Numerik dan Adversity Quotient Siswa Kelas VIII SMP Negeri 1 Payangan. Tesis. Program Studi Penelitian dan Evaluasi Pendidikan, Program Pasca Sarjana Undiksha : Singaraja

Ngurah, D. N. P. 2008. Pengaruh Pendekatan Pembelajaran Heuristik Vee Dan Algoritmik Terhadap Prestasi Belajar Matematika Ditinjau Dari Bakat Numerik Siswa SMP. Tesis (tidak diterbitkan). Program Studi Penelitian dan Evaluasi Pendidikan, Program Pascasarjana. Singaraja: Universitas Pendidikan Ganesha.

Redhana, I W. 2003. Meningkatkan kemampuan berpikir kritis siswa melalui pembelajaran kooperatif dengan strategi pemecahan masalah. Jurnal Pendidikan dan Pengajaran IKIP Negeri Singaraja, 3 (33): 11-23.
Snodgrass, S. 2011. Wiki Activities in Blended Learning for Health Professional Students: Enhancing Critical Thinking and Clinical Reasoning Skills. Australian Journal of Educational Technology. Volume:nomer, Callaghan, NSW: The University of Newcastle.

Veenman, S., Denesssen, E., M. Akker, A. V. D., Rijt, J. V. D. 2005. Effects of a cooperative learning programo $n$ the elaborations of students during help seeking and help giving. American educational research journal. 42(1). 115-151.

Warpala, I. W. S. 2006. Pengaruh pendekatan pembelajaran dan strategi belajar kooperatif yang berbeda terhadap pemahaman dan kemampuan berpikir kritis dalam pembelajaran IPA SD. Disertasi (tidak diterbitkan). Program Studi Teknologi Pembelajaran, Program Pascasarjana Universitas Negeri Malang. 